\title{
DETECTION OF SLAG INCLUSIONS IN MMA JOINTS WITH PASSIVE THERMOGRAPHY TECHNIQUES
}

\author{
Wojciech JAMROZIK, Jacek GÓRKA, Marta KIEL-JAMROZIK \\ Silesian Univ. of Technology, Department of Fundamentals of Machinery Design, Konarskiego str. 18a, \\ 44-100 Gliwice, wojciech.jamrozik@ polsl.pl \\ Silesian Univ. of Technology, Department of Welding Engineering, Konarskiego str. 18a, 44-100 Gliwice, \\ jacek.gorka@polsl.pl \\ Silesian Univ. of Technology, Department of Biomaterials and Medical Devices Engineering, Roosevelta \\ str. 40, 41-800 Zabrze, marta.kiel-jamrozik@ polsl.pl
}

\section{Abstract}

Arc welding with coated electrode, called also manual metal arc wetehilding (MMA) is one of the most popular welding methods. One of the disadvantages of this method is the formation of slag inclusions caused by improper removal of slag from the previously made bead, too little heat supplied to the joint or too little gap in the height of the root. Such inclusions significantly reduce the mechanical properties of the joint, eliminating them already at the manufacturing stage is important from the point of view of ensuring the quality of the products. A method of detecting solid inclusions in the weld using infrared monitoring has been proposed. Thermograms were subjected to Fourier 2D transformation. For the two-dimensional spectra

(F-images) images obtained in this way, point features describing the weld condition in a given measuring window were determined. The results of the analyses plotted as a function of the electrode path allowed for their comparison with X-rays and selection of F-image features, the best in terms of detection of slag inclusions in welds.

Keywords: Manual metal arc welding, slag inclusions, thermography, signal analysis, detection

\section{WYKRYWANIE WTRĄCEŃ ŻUŻLA W SPONACH WYKONANYCH METODĄ MMA Z ZASTOSOWANIEM TECHNIK TERMOGRAFI PASYWNEJ}

\section{Streszczenie}

Spawanie łukowe elektrodą otuloną jest jedną z najpopularniejszych metod spajania. Jedną z wad tej metody jest powstawanie wtrąceń żużla powodowanych niewłaściwym usunięciem żużla z poprzednio wykonanej spoiny, zbyt małą ilością ciepła doprowadzonego do złącza lub zbyt małym odstępem w wysokości grani. Wtrącenia takie znacznie obniżają własności mechaniczne złącza ich wyeliminowanie już na etapie wytwarzania jest ważne z punktu zapewnienia odpowiedniej jakości produktów. Zaproponowano metodę wykrywania wtrąceń stałych $\mathrm{w}$ spoinie, $\mathrm{z}$ zastosowaniem monitorowania $\mathrm{w}$ podczerwieni. Termogramy poddano transformacji Fouriera 2D. Dla tak otrzymanych obrazów widm dwuwymiarowych (F-obrazów) wyznaczono cechy punktowe opisujące stan spoiny w danym oknie pomiarowym. Wyniki analiz wykreślone w funkcji drogi elektrody pozwoliły na ich zestawienie $\mathrm{z}$ rentgenogramami i wybór cech F-obrazów, najlepszych z punktu widzenia detekcji wtrąceń żużla w spoinach.

Słowa kluczowe: spawanie elektrodą otuloną, wtrącanie żużla, termowizja, analiza sygnałów, detekcja

\section{INTRODUCTION}

Manual metal arc (MMA, method no. 111) welding is a method of metallic material joining, where the electric arc burns between coated electrode and workpiece. It can be applied to weld almost all steel grades (unalloyed steels, highstrength steels, power steels, high-alloy steels), copper, nickel, grey cast iron for repair welding $[11,21]$ and to make hardfaced coatings [4, 10]. The process can be carried out in the air and under the water $[12,14]$. The main difference to other welding methods is a fact that welding electrode in
MMA is shortening during joining process. According to that electrode holder must be moved toward the seam line to keep the constant arc length. Electrode in MMA is a metal rod in a special coating. The purpose of coating is to protect welding pool from surrounding air and to produce slag that also protects joint against environmental conditions and assures proper cooling rate of joint $[8,15]$. There is no shielding gas, as the welding electrode is coated with a material that produces shielding gas and a layer of slag over the molten weld pool. Successful welding results depend on the following factors and parameters: 
- the correct electrode type,

- the correct electrode size for the case,

- correct welding current,

- correct arc length,

- correct angle of electrode to weld plane,

- correct welding speed,

- correct preparation of metal pieces to be joined.

In terms of metallurgy, basic, acid, rutile and cellulose electrodes are distinguished. The slag of each of these electrodes affects the plastic and strength properties of the weld in different ways. With basic electrodes, the best weld properties are obtained, but the slag is difficult to remove. These electrodes are used for welding structural steels prone to cold cracks. The most versatile are rutile electrodes, which are characterized by easy slag removal while ensuring good weld properties [12].

According to above listed requirements, there are several conditions, that should be fulfilled in order to produce joint of high quality. As technological parameters can be repeated, the influence of welder behaviour and skills is the main factor that can increase the possibility of entrapping slag (slag inclusions, imperfection no. 3012) in a welded joint.

There is a lot of scientific groups working on monitoring of welding process condition on-line. Different approaches are applied to check the stability of the process as well as investigate presence and scale of imperfections. There are methods in which electric process signals $[6,19]$, thermography $[1,3,7]$, vision light cameras [16, $19]$, spectrometers $[18,19,20]$ or acoustic emission sensors [15] were applied. Nevertheless, several methods can be successfully applied for process monitoring and assessment of welded joints quality, all of them can be only applied form automatized and robotized welding stands, where welding parameters, like welding speed or additional material feed rate are constant. None is used to monitor manual welding.

In the MMA process real-time monitoring, controlling and detecting of process and seam quality is a task, that is hardly ever made. Nowadays quality of seams that are made with this manual technique is assessed mainly after the welding with use of different non-destructive testing (NDT) methods. To reveal slag inclusions ultrasonic examinations [16] as well as radiographic (X-ray) testing [2] can be used. Both of those methods can be applied rather off-line on the quality check stand, but there are some attempts to use those method on-line in the production process [2].

For example, high-density inclusions like tungsten appear bright when radiographed. In parts of a weld where the energy is not absorbed by the object, the radiographic image will show darkness. For example, cracks and porous areas of welds will look like dark outlines. Low-density inclusions of materials like slag will look darker on the radiographic image. X-ray are in most cases far easier to interpret as result of ultrasound testing. Additionally, certainty of obtained results is also higher in the case of X-ray testing [2].

Both of mentioned methods have one serious drawback. It is difficult to apply them on-line, to examine all produced detail. Additionally, for UT there are serious demands from personnel in terms of results understanding.

In the paper an on-line method for detection of slag inclusions in MMA seams is presented. It is based on complex analysis of thermograms acquired during realization of welding process. Fourier transform is used to generate so called Fimages (2D spectra), that are next evaluated with the use of several feature types.

\section{THERMOGRAM ANALYSIS}

To assess the state of seam in a certain moment of time the spectral representation of thermal images was chosen. It is obtained using twodimensional Fourier transform. The shift invariance [9] is one of key properties of 2D Fourier transform. It makes the method less sensitive to changes in the location of IR camera while observing welding process. There is also a possibility, that a valuable information, that is not visible in the thermogram could be emphasized.

The quantitative evaluation of thermograms was made with three types of features. Those features are applied to evaluate the mean energy as well as symmetry of the $2 \mathrm{D}$ spectrum (F-image).

The first group of features (fig. 1a) was chosen to determine the mean F-image energy in a horizontal (HFP - Horizontal Fourier Parameter) or vertical (VFP - Vertical Fourier Parameter) region placed symmetrically around the horizontal and vertical axes of symmetry. There is on parameter for each feature, that can be used for tuning, and it is the height/width of region in which the mean value is calculated [3].

$$
\begin{aligned}
& H F P=\frac{1}{X H} \sum_{x=1}^{X} \sum_{y=\frac{X-H}{2}+1}^{(Y+H) / 2} F(x, y) \\
& V F P=\frac{1}{Y V} \sum_{y=\frac{X-W}{2}+1}^{(X+W) / 2} \sum_{y=1}^{Y} F(x, y)
\end{aligned}
$$

where: $\mathrm{X}$ - F-image width, Y - F-image height (both in pixels), $\mathrm{W}$ - width of vertical analysis region, $\mathrm{H}$ - width of horizonal analysis region, $\mathrm{F}(\mathrm{x}, \mathrm{y})$ - F-image pixel value at $(\mathrm{x}, \mathrm{y})$ position.

To calculate the second group of features the assumption was made, that there should a symmetry in $2 \mathrm{D}$ spectrum of correct sample. Disturbances in temperature distribution introduced by inclusions will affect the F-image symmetry. According to that four types of spectral features (Fig. 1b) were developed. First two are applied to asses horizontal $\mathrm{QE}_{\mathrm{H}}$ and vertical $\mathrm{QE}_{\mathrm{V}}$ symmetry of F-image. The features were calculated by comparing energy in 
top- bottom (eq. 3) quarters of F-image and leftright quarters (eq. 4) respectively. The axial symmetry was evaluated using differences between energy in F-image quarters separated by diagonal $\left(\mathrm{QE}_{\mathrm{DI}}\right.$ eq. 5) and antidiagonal ( $\mathrm{QE}_{\mathrm{ADI}}$ eq. 6).

$$
\begin{aligned}
Q E_{H}= & \left(Q E_{2}+Q E_{1}\right)-\left(Q E_{3}+Q E_{4}\right) \\
Q E_{V}= & \left(Q E_{2}+Q E_{3}\right)-\left(Q E_{1}+Q E_{4}\right) \\
& Q E_{D I}=Q E_{3}-Q E_{1} \\
& Q E_{A D I}=Q E_{2}-Q E_{4}
\end{aligned}
$$

a)

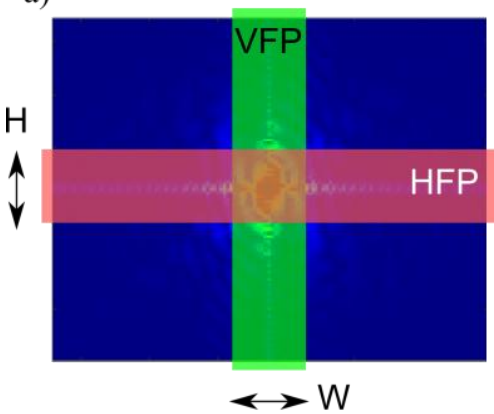

b)

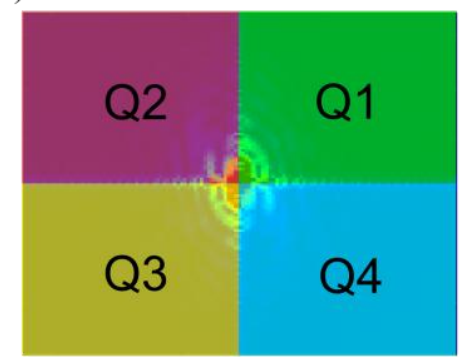

c)

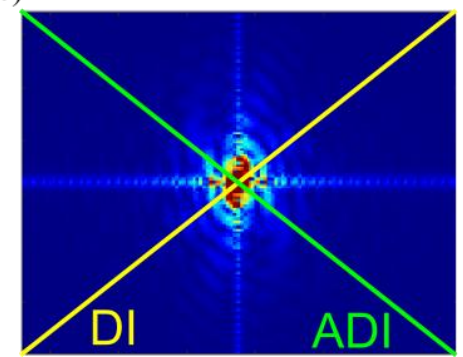

Fig. 1. Graphical illustration of F-image feature calculation

The last proposed F-image feature was calculated also the check symmetry of F-image, but in this case, the energy have been calculated along diagonal and antidiagonal (fig. 1c). To found the degree of symmetricity $\left(\mathrm{DE}_{\mathrm{S}}\right)$, the difference between obtained energy levels was calculated (eq. 7).

$$
D E_{S}=D E_{D I}-Q E_{A D I}
$$

\section{CASE STUDY}

The MMA process in conducted manually. According to that, the welder should keep constant distance from welded detail to maintain welding arc of constant length. Additionally, it is also demanded to hold the same welding speed through the whole process realization. Despite the quality of welder skills there are always some variations in welding speed. To overcome that inconvenience the welding pool tracing method was developed. It is based on emissivity change in the area where liquid metal is present in comparison to the welding tip an area where metal in seam solidified (fig. 2). The welding tip was found as an apparently coldest point $\left(\mathrm{T}_{\mathrm{MIN}}\right)$ on the axis passing through two hottest points (pixels) located on both sides of welding pool (with certain vertical offset $\mathrm{U}_{\mathrm{MAX}}-\mathrm{L}_{\mathrm{MAX}}$ ). Because during the welding process observation IR camera was in fixed location, the welding tip was changing its location in the $\mathrm{x}$-axis (direction of welding) Observing the electrode tip allowed to bound respective thermograms with location of electrode on the welded workpiece. It leads to removal of IR images that represent the welders move, that have no progressive manner. This image sequence processing operation allows further analysis of obtained thermograms in terms of localizing welding inconsistencies, and especially slag inclusions.

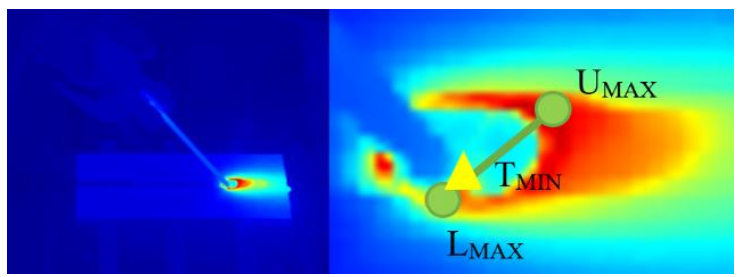

Fig. 2. Exemplary thermogram of MMA process (left), electrode tip tracking idea (right)

There were eight samples made with different welded by an experienced welder. All samples were joined with two consecutive seams. Two groups of samples were generated. In the first group after first pass, seam remained unclean, with slag on the seam face. In the second group seam made in the first pass was mechanically cleaned, to remove all unwanted pieces of slag and spatter. In the next part of the paper comparative analysis of exemplary samples that are belonging to one of groups is presented and commented. For all samples, the welding process was carried out with basic coated electrodes E 424 B 42 H5 with a diameter of 3.2 $\mathrm{mm}$. Before welding, the electrodes were dried at $300^{\circ} \mathrm{C}$ for two hours. Slag alkaline electrodes are the most difficult to remove in the production process, so it was decided to make such a choice. The welding current was 120A DC+. Test samples were of size $100 \times 120 \times 10 \mathrm{~mm}$.

IR images were acquired using uncooled microbolometer IR camera VarioCam HR head 600 , with spatial resolution of $640 \times 480 \mathrm{px}$. The recording frequency was $60 \mathrm{~Hz}$. For all welded samples constant emissivity was set and emissivity changes in function of temperature were not took into consideration. It is an international procedure, because, it was assumed, that slag, has other properties than molten and solidified metal. Those differences are used to detect inclusions as an 
anomaly in the pure joint, that is characterized by homogeneous properties.

\section{RESULTS}

Two samples were selected for comparison. The choose was made according to results of radiographic testing that revealed two slag inclusion in one of samples. All features described in sec. 2 were calculated to describe condition/quality of joint. For both samples, the joint was $110 \mathrm{~mm}$ long, and it was made in two pass welding. Beside slag inclusion there were also other welding inconsistencies, like incomplete root penetration (imperfection no. 4021) are present in both samples. Those defects are not significantly influencing proposed method for slag detection.

\subsection{Sample with slag}

For the sample with slag inclusion two area with defects were found (fig. $3 \mathrm{~b}$, marked in circles) at $4^{\text {th }}$ and $7^{\text {th }} \mathrm{cm}$ of joint length. Slag is clearly visible in the form of darker, circular areas in the radiogram.

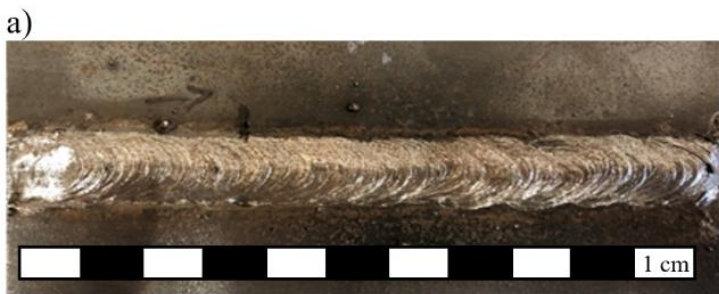

b)

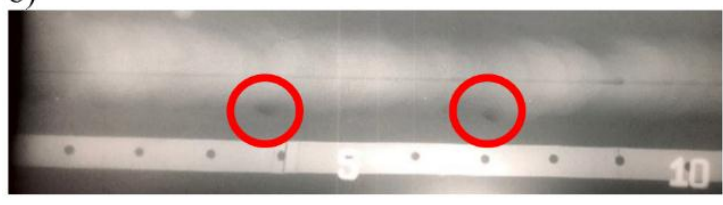

Fig. 3. Welded sample with slag inclusions: a) face view, b) radiogram of joint
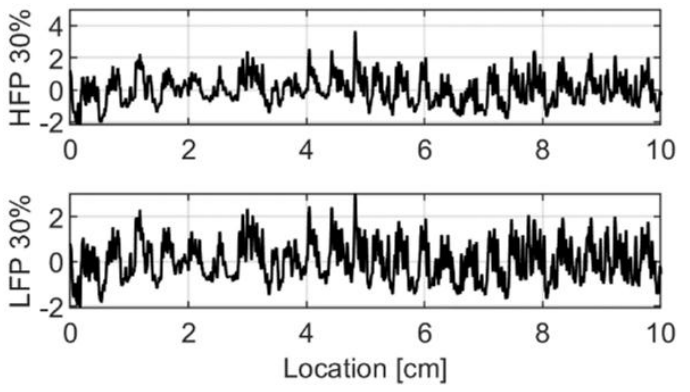

Fig. 4. HFP and LFP features for sample with slag inclusions calculated for sequence of thermograms without electrode tip tracking

In the fig. 5 there are slag inclusion locations marked (red circles). Applying constant threshold those locations can be detected in the HFP signal. For the LFP, inclusion on $4^{\text {th }}$ centimetre is easier to distinguish. There are also locations with false positive detections (blue circles). Introducing threshold of range, e.g. $+/-10 \%$ of boundary value, number of false detections can be reduced. Moreover, there are no true detections omitted.

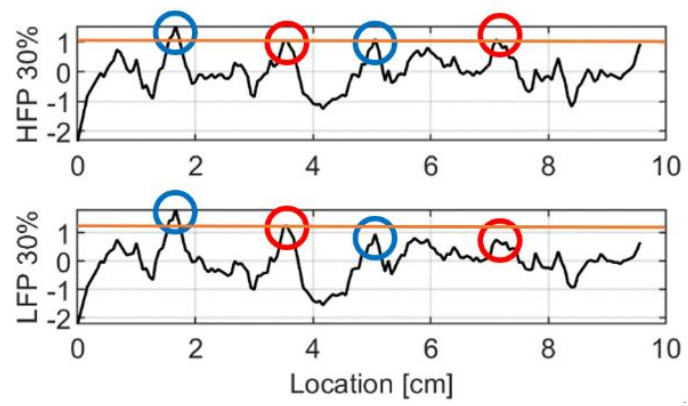

Fig. 5. HFP and LFP features for sample with slag inclusions

The low frequencies are placed in the middle of F-image, thus for the narrower region of analysis energy located in higher frequencies is omitted. In fig. 6 there can be seen, that the difference between features calculated for $30 \%$ and $50 \%$ image height region is small. As there are mainly low frequencies in the F-image the main IR image content is the temperature pattern, rather the edge distribution. Anomalies in temperature distribution on the solidified joint surface, as well as presence of even partially unmelted object (despite of its shape or sharpness) in the welding pool will affect the low frequency part of the F-image.

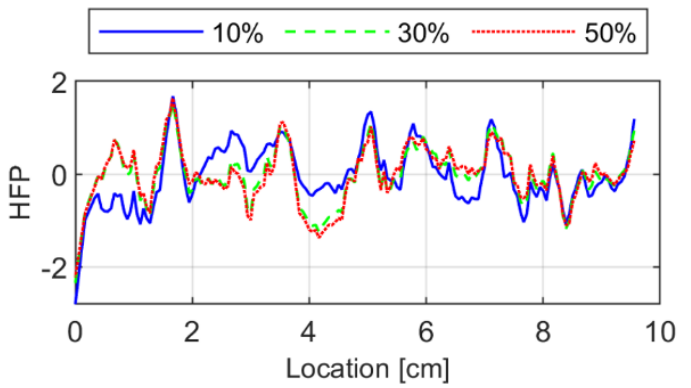

Fig. 6. Influence of region of analysis size on HFP for sample with slag

Diagonal energy features and diagonalantidiagonal symmetry feature have been regarded as lees useful in detecting slag inclusions. For the diagonal energy feature $\mathrm{DE}_{\mathrm{DI}}$ (fig. 7), when the threshold was set on 1,7 this feature can be applied for slag detection. The upper limit was chosen based on all made samples, to create a boundary between samples with and without inconsistencies.
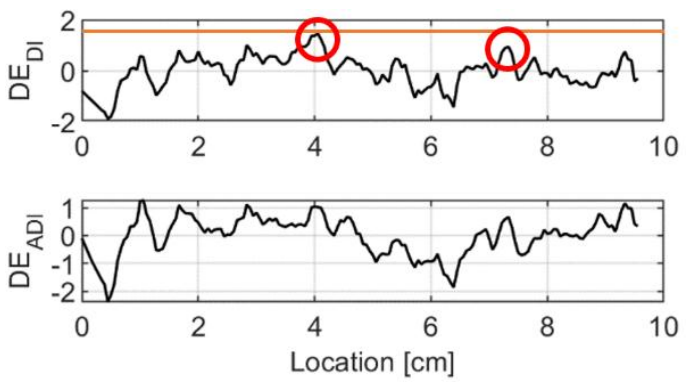

Fig. 7. F-image energy on diagonal and antidiagonal for sample with slag 


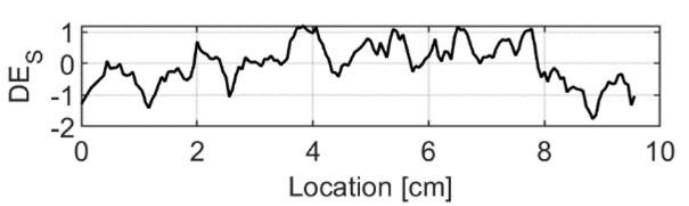

Fig. 8. Symmetry between diagonal and antidiagonal energy for sample with slag

Area symmetry based features gave results that are not convincing. Only $\mathrm{QE}_{\mathrm{V}}$ describing symmetry between F-image top-bottom quarters point feature allowed on-line detection of inclusions with desired quality. Moreover the time delay influencing the localization error is negligible. For $\mathrm{QE}_{\mathrm{H}}, \mathrm{QE}_{\mathrm{DI}}$ and $\mathrm{QE}_{\mathrm{ADI}}$ features plots in the function of electrode travelled distance remain unstable for the whole sample length.
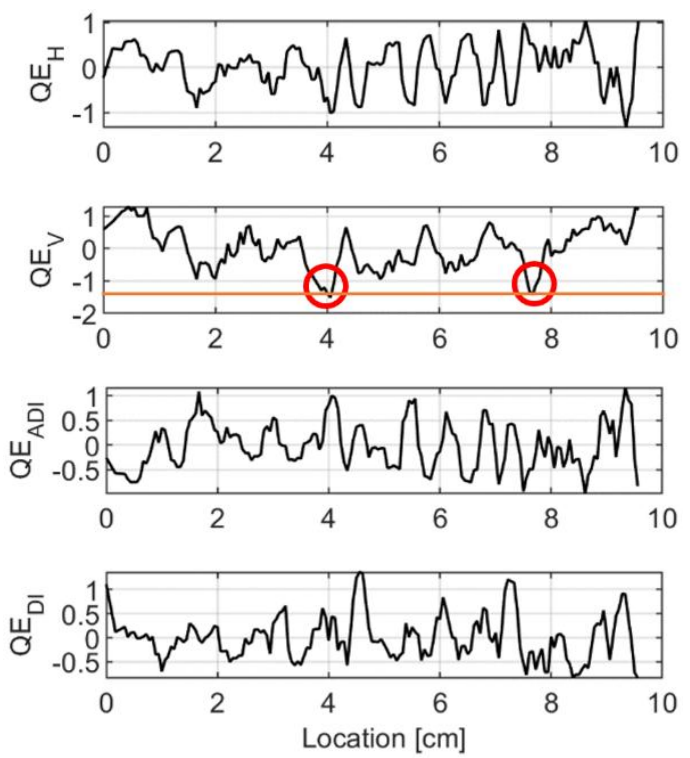

Fig. 9. Quarter symmetry energy indicators calculated for sample with slag inclusions

\subsection{Sample without slag}

For the sample, when between seems all impurities were mechanically removed, analysis radiogram does not reveal any inclusions.

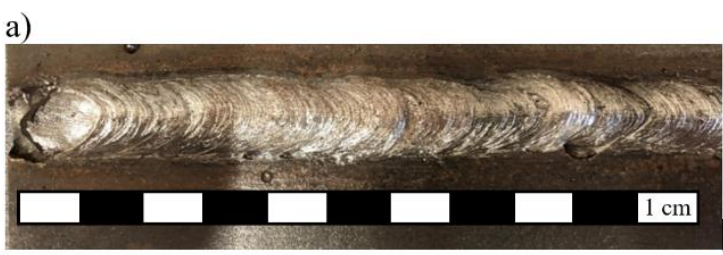

b)

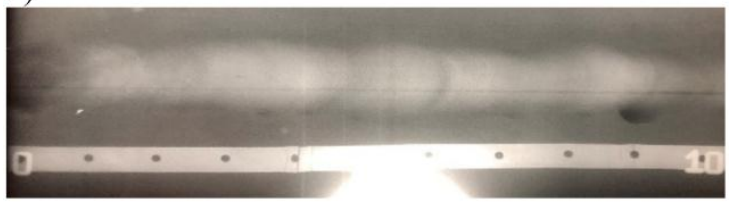

Fig. 10. Welded sample without slag inclusions: a) face view, b) radiogram of joint
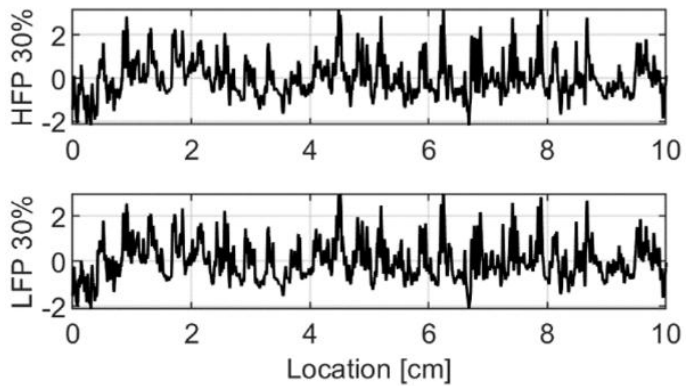

Fig. 11. HFP and LFP features for sample without slag inclusions calculated for sequence of thermograms without electrode tip tracking

In fig. 4 and fig. 11 there are HFPs and LFPs for two welded samples, where electrode tip tracking was omitted. All thermograms acquired during welding were in this case transformed to frequency domain with 2D Fourier transform and assessed. Comparing those with features where position was tracked and repeating positions removed from plot (fig. 5, fig. 12), it can be noticed that unconditioned plots are characterized by higher level of noise and signal changing rate, that has impulsive characteristic. No clear detection can be made analysing those signals, because, there is no real correspondence between slag inclusions and signal properties, because one can observe amplitude-time rather than amplitude-location dependency.
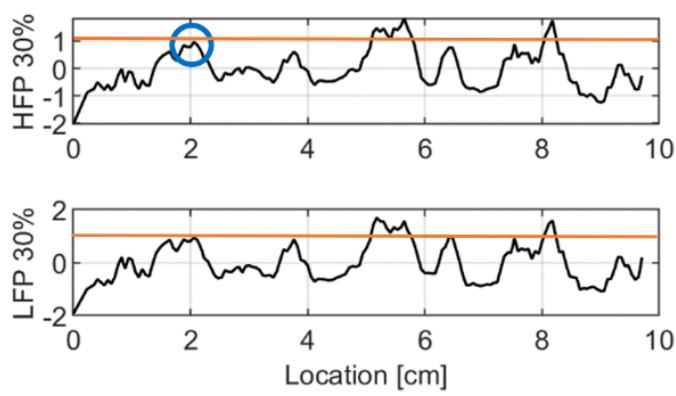

Fig. 12. HFP and LFP features for sample without slag

Comparing HFP $30 \%$ for sample with slag (fig. 5) inclusion and sample without (fig. 12) it can be seen, that there is a noticeable increase of feature, when the inclusion is present. Nevertheless, there also other locations, where the feature value increases. Taking into consideration only those where feature values varies not more than $10 \%$ from the HFP value for detected inclusions, there is one such location that can be regarded as a false positive inconsistency detection. Those false detections can be connected to the slag particles or other impurities that are present in welding poll or in the solidification zone. This type of corpuscles can be registered during welding process but finally they are removed from joint by forces generated by welding arc or they are melted out.

Symmetry based feature taking energy on the diagonal $\left(\mathrm{DE}_{\mathrm{DI}}\right)$ of $\mathrm{F}$-image was the most useful feature from this group. In this case no false positive detections were made (fig. 13), because in 
this case upper limit was on the level 1,7. It can be seen for both presented samples, that there is quite large difference between symmetry on diagonal and antidiagonal of F-Image. It can be caused by the fact, that thermograms were taken by IR camera, which optical axis was not perpendicular to the welding pool and seam plane.
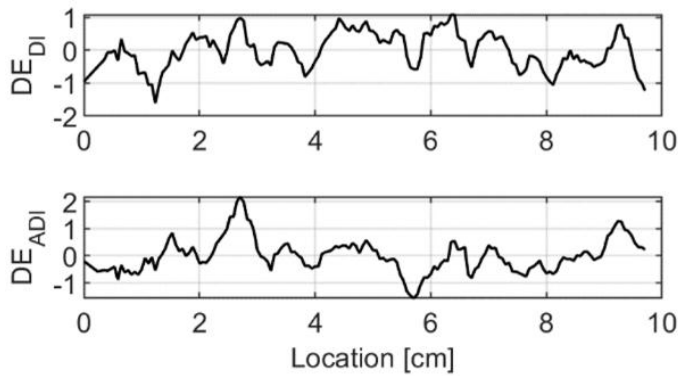

Fig. 13. F-image energy on diagonal and antidiagonal for sample without slag

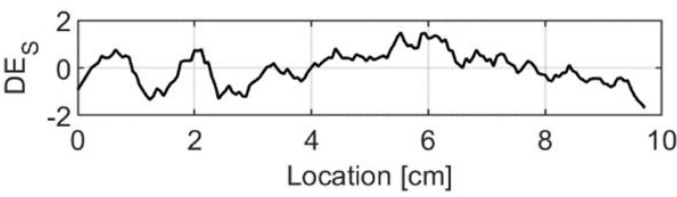

Fig. 14. Symmetry between diagonal and antidiagonal energy for sample without slag
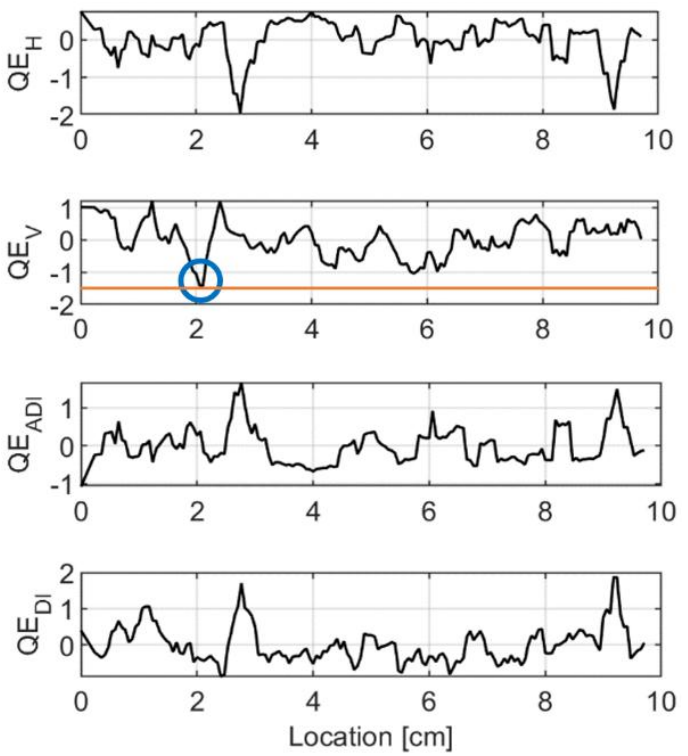

Fig. 15. Quarter symmetry energy indicators calculated for sample without slag inclusions

For quarter symmetry features only for $\mathrm{QE}_{\mathrm{V}}$ the boundary between sound joint and one with slag inclusions was found. One false positive detection was made, and no false negative detections were found. In this case the detection certainty was high. Difference between features describing sound joint and incorrect one was on average level of 0,5 , when the lower limit was set on -1,5. It is a better result than for HFP feature, where differences were smaller, and more misclassifications appeared.

\section{CONCLUSIONS}

In the paper preliminary studies concerning the possibility of slag inclusion detection in MMA method using IR monitoring. Sequences of thermograms taken during the welding process, were transferred to the frequency domain using $2 \mathrm{D}$ Fourier transform. Several feature types were proposed to evaluate resulting F-images. According to obtained results features that are measuring mean energy of F-image in the region are the most promising ones when dealing with slag inclusion detection and localization. Additionally vertical quarters symmetry features $\mathrm{QE}_{\mathrm{V}}$ gave also noticeable results. It can be observed, that applying selected features, there are some false positive detections, but no false negative detections were observed.

As all tests were made on a limited set of samples, to generalize obtained results it is demanded to perform research on an expanded data set. According to that in future studies more samples have to be welded, containing different slag inclusion volume.

\section{SOURCE OF FUNDING}

This work was partially supported by Statutory Founds of Faculty of Fundamentals of Machinery Design, Silesian University of Technology, Gliwice.

\section{REFERENCES}

1. Alfaro SCA, Vargas JAR, De Carvalho GC, De Souza GG. Characterization of "humping" in the GTA welding process using infrared images. J Mater Process Technol. 2015; 223: 216-224, https://doi.org/10.1016/j.jmatprotec.2015.03.052

2. Du D, Cai G, Tian Y, Hou R, Wang L. Automatic inspection of weld defects with $\mathrm{x}$-ray real-time imaging. In: Tarn TJ, Chen SB, Zhou C. (eds) Robotic Welding, Intelligence and Automation. Lecture Notes in Control and Information Sciences, vol 362. Springer, Berlin, Heidelberg. 2017;362. https://doi.org/10.1007/978-3-540-73374-4_43

3. Fidali M, Jamrozik W. Method of classification of global machine conditions based on spectral features of infrared images and classifiers fusion. Quant InfraRed Thermography J. 2019; 16(1): 129-145. https://doi.org/10.1080/17686733.2018.1557453

4. Górka J, Czupryński A, Adamiak M. Properties and structure of nanocrystalline layers obtained by Manual Metal Arc Welding (MMA) 2017 Archives of Metallurgy and Materials. 2017; 62(3): 1479-1484, https://doi.org/10.1515/amm-2017-0229

5. Górka J, Jamrozik W. Application of time-frequency methods for assessment of gas metal arc welding condition. In: Awrejcewicz J. (eds) Dynamical Systems in Applications. DSTA 2017. Springer Proceedings in Mathematics \& Statistics, Springer, Cham. 2018;249:125-133. https://doi.org/10.1007/978-3-319-96601-4_12

6. Huang Y, Wang K, Zhou Q. et al. Feature extraction for gas metal arc welding based on EMD and time- 
frequency entropy. Int J Adv Manuf Technol. 2017; 92: 1439-1448. https://doi.org/10.1007/s00170-0169921-5

7. Jamrozik W. Modified random walker segmentation method of welding arc thermograms for welding process diagnostics. Int $\mathrm{J}$ Mater Prod Technol 2015;51(3):281-295.

https://doi.org/10.1504/IJMPT.2015.072247

8. Moore P, Booth G. Welding problems and defects, The Welding Engineers Guide to Fracture and Fatigue, 2015.

9. Nixon SM, Aguado S. Feature extraction and image processing. Oxford, Boston: Newnes; 2002

10. Reisgen U, Stein L, Balashov B, Geffers C. Nanophase hardfaced coatings. Materialwissenschaft und Werkstofftechnik. 2009;40:618-622. https://doi.org/10.1002/mawe.200800454

11. Weman K, Manual metal arc (MMA) welding with coated electrodes, In: Weman K. ed., Woodhead Publishing Series in Welding and Other Joining Technologies, Welding Processes Handbook (Second Edition), Woodhead Publishing. 2012: 99-103. https://doi.org/10.1533/9780857095183.99.

12. Węgrzyn T, Wieszala R. Significant alloy elements in welded steel structures of car body. Archives of Metallurgy and Materials. 2012; 57(1): 45-52 https://doi.org/10.2478/v10172-011-0151-4

13. Tomków J, Fydrych D, Rogalski G. Role of bead sequence in underwater welding. 2019, Materials, 12(20): 3372, https://doi.org/10.3390/ma12203372

14. Tomków J, Rogalski G, Fydrych D, Labanowski J, Advantages of the application of the temper bead welding technique during wet welding. Materials. 2019; 16(6):915. https://doi.org/10.3390/ma12060915

15. Zhang L, Basantes-Defaz AC, Ozevin D. et al. Realtime monitoring of welding process using air-coupled ultrasonics and acoustic emission. Int J Adv Manuf Technol. 2019; 101: 1623-1634. https://doi.org/10.1007/s00170-018-3042-2

16. Zhang L, Mostavi A, Basantes-Defaz A, Ozevin D, Indacochea JE. The measurement of weld morphology and inclusions using ultrasonics. Measurement. 2019;144:33-43. https://doi.org/10.1016/j.measurement.2019.04.088

17. Zhang L, Su S, Wang L, Chen J. Investigation of arc behaviour and metal transfer in cross arc welding, Journal of Manufacturing Processes. 2019; 37:124129. https://doi.org/10.1016/j.jmapro.2018.11.01

18. Zhang Y, Zhang N, You D, Gao X, Katayama S. High-power disk laser welding statuses monitoring based on analyses of multiple-sensor signals. J Manuf Processes. 2019;41:221-230. https://doi.org/10.1016/i.jmapro.2019.03.028

19. Zhang Z, Chen H, Xu Y, Zhong J, Lv N, Chen S. Multisensor-based real-time quality monitoring by means of feature extraction, selection and modeling for Al alloy in arc welding. Mech Syst Signal Process 2015;60:151-165.

https://doi.org/10.1016/j.ymssp.2014.12.021

20. Zhang Z, Kannatey-Asibu E, Chen S. et al. Online defect detection of $\mathrm{Al}$ alloy in arc welding based on feature extraction of arc spectroscopy signal. Int $\mathbf{J}$ Adv Manuf Technol. 2015; 79:2067-2077. https://doi.org/10.1007/s00170-015-6966-9

21. Żuk M, Górka J, Dojka R, Czupryński A. Repair welding of cast iron coated electrodes, 2017 IOP Conference Series: Materials Science and
Engineering 227(1), https://doi.org/10.1088/1757$\underline{899 X / 227 / 1 / 012139}$

Received 2020-02-25

Accepted 2020-05-26

Available online 2020-05-28

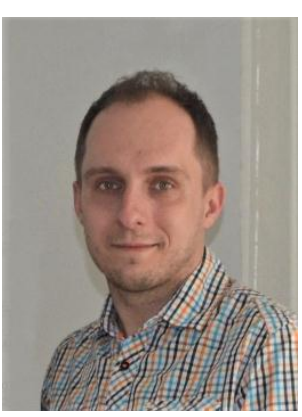

Wojciech JAMROZIK, BEng, $\mathrm{PhD}$. Currently he is employed as an assistant professor in the Department of Fundamentals of Machinery Designs, SUT. Member of the Polish Society of Technical Diagnostics. His interests involve thermography, vibroacoustic, condition monitoring, welding diagnosing and quality monitoring, application of artificial intelligence methods in technical diagnostics.

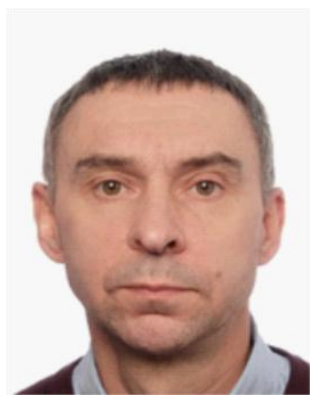

Jacek GÓRKA, BEng, PhD, DSc, Assoc. Prof. Head of the Department of Welding Engineering, SUT. Holds the EWE (European Welding Engineer) competence certificate. Research areas: weldability of modern construction materials, metallurgy of welding processes, quality control of welding processes, abrasive and erosive wear processes and the use of nanostructured carbon materials to modify the properties and structure of welds, plasma cutting.

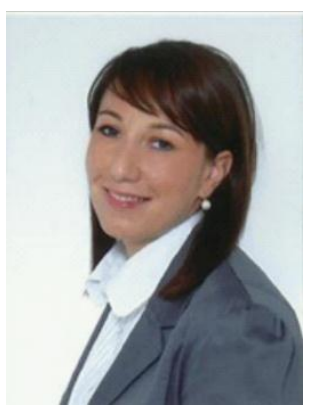

Marta KIEL-JAMROZIK, BEng, PhD. Assistant Professor at Department on Biomaterials and Medical Devices Engineering, Faculty of Biomedical Engineering, Silesian University of Technology.

Her scientific interests are: biomaterials, implants, Surface modification, research of mechanical properties physicochemical properties, 3d printing. 